\title{
CHEWING LICE (Phthiraptera) FROM CRESTED CARACARA (Caracara plancus, Falconidae) IN SOUTHERN BRAZIL
}

\author{
OLIVEIRA, Plínio Aguiar de ${ }^{1}$; \\ RUAS, Jerônimo Lopes ${ }^{2}$; \\ SANTOS, Luciana Siqueira ${ }^{3}$; \\ MARTINS, Natália Soares ${ }^{3}$; \\ MOTTA, Sara Patron da ${ }^{3}$; \\ SANTOS, Carolina Caetano dos ${ }^{3}$; \\ PAPPEN, Felipe Geraldo ${ }^{4}$; \\ FARIAS, Nara Amélia da Rosa ${ }^{5}$.
}

\footnotetext{
${ }^{1}$ Médico Veterinário, Professor, Doutor, Curso de Medicina Veterinária, Instituto de Desenvolvimento Educacional de Bagé (UNIDEAU); ${ }^{2}$ Médico Veterinário, Doutor, Laboratório Regional de Diagnóstico, Faculdade de Veterinária, UFPEL; ${ }^{3}$ Doutoranda, Programa de Pós-Graduação em Microbiologia e Parasitologia, Instituto de Biologia, UFPEL; ${ }^{4}$ Médico Veterinário, Professor, Doutor, Departamento de Veterinária Preventiva, Faculdade de Veterinária, UFPEL; ${ }^{5}$ Médica Veterinária, Professora, Doutora, Instituto de Biologia, UFPEL.
}

\section{ABSTRACT}

T his study was carried out to detect chewing lice species occurring on Crested Caracara (Caracara plancus) in Southern Brazil between January 2014 and December 2018. For this aim, the road-kill birds were collected for parasitological studies at the Biology Institute, Department of Microbiology and Parasitology of the Federal University of Pelotas. Fourteen road-kill birds were examined for ectoparasites. The birds were washed with water and detergent for the collection of ectoparasites by filtration using a $150 \mu \mathrm{m}$ mesh sieve. The samples were separated into pellet and supernatant and were kept in microcentrifuge tubes containing ethyl alcohol $70 \%$ for the screening procedures and identification. A total of 794 specimens of lice were collected and examined, presenting the following breakdown by Amblycera suborder: Colpocephalum flavescens (753/94.84\%), Laemobothrion vulturis (9/1.13\%), and Ischnocera suborder: Caracaricola chimangophilus (30/3.78\%) and Lipeurus sp. (2/0.25\%). It was found that all the caracara examined were parasitized by one or more species of Phthiraptera, with multiple or moderate level of infestation (101 to 1,000 lice/birds). C. flavescens was the most frequent and abundant species with $100 \%$ of the birds parasitized and an average of 53,7 lice/birds.

Keywords: Caracara plancus. Phthiraptera. Ectoparasites. 


\section{INTRODUCTION}

Crested Caracara (Caracara plancus) is a unique raptor/scavenger in the Falconidae family (MORRISON, 2006). It is found from the Southern USA to Tierra del Fuego in open spaces, such as grasslands, savannas, pastures, cultivated fields, swamplands, road edges, highways, cities, and rural areas. In South America, the habitat of Crested Caracara has expanded along with the increase of human activities, due to a marked synanthropic behavior including nesting on human structures showing behavioral plasticity and described as dietary opportunists. At the same time, trees in this part of Southern Brazil have been typically removed from fields, they are found scattered along the roadside (DEL HOYO et al., 1994; GOLDSTEIN, 2000; PALMER, 1988; SIGRIST, 2006).

According to several studies, the most common causes of morbidity in these birds are infectious and parasitic diseases, toxicosis and metabolic, nutritional diseases, or traumatic injuries (ANDERY et al., 2013). Road kills are amongst the major cause of traumatic injuries probably due to raptor movement seeking food, mostly mammals and birds previously get hit on the highways (ANDERY et al., 2013). Road and highway construction affect wildlife through the direct loss and fragmentation of habitat, by introducing a source of additive mortality for wildlife populations, and by disrupting animal movement and dispersal. Traditionally, highway impacts on wildlife have been viewed in terms of road mortality and threats to selected populations of animals. Viewing this issue from a landscape ecology perspective, it is clear that highways have the potential to undermine ecological processes through the fragmentation of wildlife populations, and restriction of wildlife movements (ANDREWS, 1990; DE SANTO; SMITH, 1993).

Among the diversity of parasites that can be found in wild birds, the chewing lice (Insecta: Phthiraptera) stand out, and together with the feather mites (Acari: Acaridida), are the most often found ectoparasites (ANDERY et al., 2013; VALIM et al., 2005). The birds are parasitized by lice of two (Amblycera and Ischnocera) of the four sub-orders of Phthiraptera. Ischnocera live mainly in the feathers of their host and Amblycera live on the skin and body surface of the host; both showing high degree of specificity to a single species or a close group of hosts (VALIM et al., 2005). Although raptors infested with ectoparasites may show 
no clinical signs, severe infestation mainly by lice may cause ragged looking feathers and self-inflicted trauma; furthermore, some ectoparasites are vectors of several pathogens of rapine birds (FREITAS et al., 2002; MORISHITA et al., 2001). Veterinarians and wildlife rehabilitators frequently admit free-living raptor into their clinics or rehabilitation centers. Incoming birds require to be screened for external parasites, and infested birds can be rapidly treated.

Numerous species of lice (Phthiraptera) have been found on raptors. Bird lice have an obligatory and entire life cycle on the host and their host specificity is restricted to one or a few host species (DALE; DROWN, 2001). At sense, this study was carried out to document chewing lice of $C$. plancus killed by running over on the highways of Southern Brazil.

\section{MATERIAL AND METHODS}

Between January 2014 and December 2018, fourteen road-kill birds were collected for parasitological studies along two federal highways (Brazilian federal highways - BR 116 and BR 392) in Southern Brazil. This study was authorized by Brazilian National Environmental Agency number 28810-1. Each bird was packed in a plastic bag and carried to the Biology Institute, Department of Microbiology and Parasitology of the Federal University of Pelotas in up to six hours. For the ectoparasites collection, the birds were kept in water with a detergent solution for about 30 minutes for unfixing the parasites. The ectoparasites were fixed in $70 \%$ alcohol, clarified with $10 \%$ potassium hydroxide and mounted between a slide and a cover slip with organic Canada balsam. The identification of lice was performed according to specific bibliography (CLAY, 1950; MELO et al., 2012; PRICE et al., 2003). The parameters analyzed (prevalence, mean intensity, and mean abundance) were calculated according to Bush et al. (1997). The representative specimens were deposited on the parasitological collection of the Department of Microbiology and Parasitology of the Federal University of Pelotas.

\section{RESULTS AND DISCUSSION}

Roadkills are amongst the most significant biodiversity impacts, although little is known about the factors that influence the roadkill of neotropical birds. Raptors harbor a variety of ectoparasites and the majority of them are host specific. In spite of increased number of 
investigations about lice fauna found on bird species, the numbers of investigated wild bird and reported lice species are still insufficient in Brazil, especially in raptor/scavenger (ROSA; BAGER, 2012).

This study demonstrated that a high prevalence rate of Phthiraptera was found in fourteen birds (100\%) with 794 specimens of chewing lice (Table 1). A total of 794 specimens of lice were collected and examined, presenting the following breakdown by Amblycera suborder: Colpocephalum flavescens (753/94.84\%), Laemobothrion vulturis (9/1.13\%), and Ischnocera suborder: Caracaricola chimangophilus (30/3.78\%) and Lipeurus sp. (2/0.25\%). Chewing lice are the most prevalent ectoparasites of raptors (MORISHITA et al., 2001) and in this study the prevalence was high (100\%). This suggests that this parasitism may have weakened birds, impairing their ability to escape and more easily being hit by a car. This high prevalence disagrees with the data obtained by Pérez-Jiménez et al. (1988) in Spain (42\%) and Morishita et al. (2001) in the United States (34.3\%) from captive animals, probably because the raptors received some treatment in rehabilitation centers. Differently, here just wild animals were studied.

Table 1 - Chewing lice (Phthiraptera) from Caracara plancus in Southern Brazil.

\begin{tabular}{lccc}
\hline \multicolumn{1}{c}{ Specie } & P\% & MA & MI \\
\hline Colpocephalum flavescens & 100 & 53.78 & 53.78 \\
Caracaricola chimangophilus & 85.7 & 2.1 & 2.5 \\
Laemobothrion vulturis & 35.7 & 0.64 & 1.8 \\
Lipeurus sp. & 14.2 & 0.14 & 1.0 \\
\hline
\end{tabular}

$\mathrm{P}=$ Prevalence; $\mathrm{MA}=$ Mean Abundance; $\mathrm{MI}=$ Mean Intensity.

Among the diversity of parasites that can be found in wild birds, the chewing lice (Insecta: Phthiraptera) stand out, and together with the feather mites (Acari: Acaridida) are the most often found ectoparasites (VALIM et al., 2005). The birds are parasitized by lice of two (Amblycera and Ischnocera) of the four sub-orders of Phthiraptera. Ischnocera live mainly in the feathers of their host and Amblycera live on the skin and body surface of the host; both showing high degree of specificity to a single species or a close group of hosts (CLAY, 1950). 


\section{CONCLUSION}

The examinated Caracara plancus were parasitized by lice of the sub-orders Amblycera and Ischnocera, with high occurrence rate (100\%). Routine sampling of malophages in apprehended birds or captive may provide a better understanding of the diversity of Phthiraptera fauna in the region, due to the difficulty in capturing material in nature.

\section{PIOLHOS MASTIGADORES (Phthiraptera) EM CARCARÁ (Caracara plancus, Falconidae) NO SUL DO BRASIL}

\section{RESUMO}

- ste estudo foi realizado para detectar a ocorrência de espécies de piolhos E mastigadores em carcará (Caracara plancus) no sul do Brasil, entre janeiro de 2014 e dezembro de 2018. Para tanto, aves atropeladas desta espécie foram coletadas para estudos parasitológicos no Instituto de Biologia, Departamento de Microbiologia e Parasitologia da Universidade Federal de Pelotas. Quatorze aves atropeladas foram coletadas e examinadas para presença de ectoparasitos. As aves foram lavadas com água e detergente para a coleta de ectoparasitos por filtração, utilizando peneira de malha de 150 $\mu \mathrm{m}$. As amostras foram separadas em pellet e sobrenadante, e preservadas em microtubos contendo álcool etílico $70 \%$ para os procedimentos de seleção e identificação. Um total de 794 espécimes de piolhos foram coletados e examinados apresentando a seguinte frequência para subordem Amblycera: Colpocephalum flavescens (753/94,84\%), Laemobothrion vulturis (9/1,13\%) e subordem Ischnocera: Caracaricola chimangophilus (30/3,78\%) e Lipeurus sp. (2/0,25\%). Verificou-se que todos os caracarás examinados estavam parasitados por uma ou mais espécies de Phthiraptera, sendo o nível múltiplo e moderado de infestação (101 a 1.000 piolhos/aves) sendo $C$. flavescens a espécie mais frequente e abundante com $100 \%$ das aves parasitadas e uma média de 53,7 piolhos/aves.

Palavras-chave: Caracara plancus. Phthiraptera. Ectoparasitos. 


\section{PIOJOS MASTICADORES (Phthiraptera) EN CARACARÁ (Caracara plancus, Falconidae) EN EL SUR DE BRASIL}

\section{RESUMEN}

$\mathrm{E}$ ste estudio fue realizado para detectar la presencia de especies de piojos masticadores en caracará (Caracara plancus) en el sur de Brasil entre enero de 2014 y diciembre de 2018. Aves atropelladas de esta especie fueron recolectadas para estudios parasitológicos en el Instituto de Biología, Departamento de Microbiología y Parasitología de la Universidad Federal de Pelotas. Catorce aves atropelladas fueron recogidas y examinadas para evaluar la presencia de ectoparásitos. Las aves fueron lavadas con agua y detergente para la recolección de ectoparásitos por filtración, utilizando tamiz de malla de $150 \mu \mathrm{m}$. Posteriormente se separó el pellet y el sobrenadante, los cuales se preservaron en microtubos conteniendo alcohol etílico al $70 \%$ para los procedimientos de cribado e identificación. Se obtuvieron un total de 794 especímenes de piojos, presentando la siguiente frecuencia. Para el suborden Amblycera: Colpocephalum flavescens (753/94,84\%), Laemobothrion vulturis (9/1,13\%) y suborden Ischnocera: Caracaricola chimangophilus $(30 / 3,78 \%)$ y Lipeurus sp. (2/0,25\%). Se verificó que todos los caracarás examinados estaban parasitados por una o más especies de Phthiraptera, siendo el nivel múltiple y moderado de infestación (101 a 1.000 piojos/aves). C. flavescens fue la especie más frecuente y abundante con el $100 \%$ aves parasitadas y una media de 53,7 piojos/aves.

Palabras clave: Caracara plancus. Phthiraptera. Ectoparásitos.

\section{REFERENCES}

ANDERY, D. A.; FERREIRA JÚNIOR, F. C.; ARAÚJO, A. V.; et al. Health assessment of raptors in triage in Belo Horizonte, MG, Brazil. Brazilian Journal of Poultry Science, v. 15, n. 3, p. 169286, 2013.

ANDREWS, A. Fragmentation of habitat by roads and utility corridors: a review. Australian Journal of Zoology, v. 26, n. 3-4, p. 130-141, 1990.

BUSH, A. O.; LAFFERTY, K. D.; LOTZ, J. M.; et al. Parasitology meets ecology on its own terms: Margolis et al. revisited. Journal of Parasitology, v. 83, n. 4, p. 575-583, 1997.

CLAY, T. A preliminary survey of the distribution of the Mallophaga ("Feather lice") on the class Aves (Birds). Journal of the Bombay Natural History Society, v. 49, p. 430-443, 1950.

DALE, H. C.; DROWN, D. M. Critical evaluation of five methods for quantifying chewing lice (Insecta: Phthiraptera). Journal of Parasitology, v. 87, n. 6, p. 1291-1300, 2001. 
DE SANTO, R. S.; SMITH, D. G. Environmental auditing: an introduction to issues of habitat fragmentation relative to transportation corridors with special reference to high-speed rail (HSR). Environmental Management, v. 17, p. 111-114, 1993.

DEL HOYO, J.; ELLIOT, A.; SARGATAL, T. Handbook of the birds of the world. 2. ed. Barcelona: Lynx, 1994. 639p.

FREITAS, M. F. L.; BOTÊLHO, M. C. N.; LEITE, A. S.; et al. Ectoparasitos de aves silvestres mantidas em cativeiro no estado de Pernambuco, Brasil. Entomología y Vectores, v. 9, p. 2533, 2002.

GOLDSTEIN M. I. Nest-site characteristic of Crested Caracaras in La Pampa, Argentina. Journal of Raptor Research, v. 34, n. 4, p. 330-333, 2000.

MELO, C. M. F.; OLIVEIRA, J. B.; ATHAYDE, A. C. R.; et al. Identification of parasites in Puffinus puffinus (Birds, Procellariiformes) from Northeastern Brazil. Veterinary Research Communications, v. 36, p. 235-238, 2012.

MORISHITA, T. Y.; MERTINS, J. W.; BAKER, D. G.; et al. Ocurrence and species of lice on freeliving and captive raptors in California. Journal of Avian Medicine and Surgery, v. 15, n. 4, p. 288-292, 2001.

MORRISON, J. L. The Crested Caracara in the Changing Grasslands of Florida. In: FLORIDA DRY PRAIRIE CONFERENCE, 2006, Florida. PROCEEDINGS. Florida: FDPC, 2006. P. 211-215. Available in:

<http://www.ces.fau.edu/fdpc/proceedings/3-17145_p.21115_Mor_FDPC_d.pdf> .

PALMER, R. S. Handbook of North American Birds. New Haven: Yale University Press, 1988.

PÉREZ-JIMÉNEZ, J. M.; SOLER-CRUZ, M. D.; BENITEZ-RODRIGUEZ, R.; DIAZ-LOPEZ, M.; RUIZMARTINEZ, I. Mallophaga of Buteo b. buteo in southern Spain. Angewandte Parasitologie, v. 29, p. 189-200, 1988.

PRICE, R. D.; HELLENTHAL, R. A.; PALMA, R. L. World checklist of chewing lice with host associations and keys to families and genera. In: PRICE, R. D.; HELLENTHAL, R. A.; PALMA, R. L.; JOHNSON, K. P.; CLAYTON, D. H. (Org.). The Chewing Lice: World Checklist and Biological Overview. Illinois: Natural History Survey Special Publication, 2003.

ROSA, C. A.; BAGER, A. Seasonality and habitat types affect roadkill of neotropical birds. Journal of Environmental Management, v. 97, n. 1, p. 1-5, 2012.

SIGRIST, T. Aves Brasileiras: uma visão artística. Valinos: Avis Brasilis, 2006. 672p. 
VALIM, M. P.; TEIXEIRA, R. H. F.; AMORIM, M.; et al. Malófagos (Phthiraptera) recolhidos de aves silvestres no Zoológico de São Paulo, SP, Brasil. Revista Brasileira de Entomologia, v. 49, n. 4, p. 584-587, 2005.

Corresponding author: Jerônimo Lopes Ruas. Laboratório Regional de Diagnóstico, Faculdade de Veterinária, Universidade Federal de Pelotas, Campus Universitário, S/N, CEP 96160-000, Capão do Leão (RS). jeronimo.ruas@gmail.com 